\title{
Research
}

\section{Water Management on the Island of IJsselmonde 1000 to 1953: Polycentric Governance, Adaptation, and Petrification}

\author{
Erik Mostert $^{1}$
}

\begin{abstract}
One of the central tenets of adaptive management is polycentric governance. Yet, despite the popularity of the concept, few detailed case studies of polycentric governance systems exist. In this paper, we aim to partly fill this gap. We describe water management between the years 1000 and 1953 on the Dutch island of IJsselmonde in the Netherlands near Rotterdam, and then use this case to reflect on the theory of polycentric governance. Despite the small size of the island, water management on IJsselmonde was the responsibility of no fewer than 31 local jurisdictions and some 65 polders. In addition, some supra-local arrangements were made, such as joint supervision of dikes. According to the theory, such a polycentric system should have many advantages over more centralized management systems, and indeed there is some evidence of this. Yet, there is also evidence of a disadvantage that is not mentioned in the literature: petrification. IJsselmonde's water management system was often slow to adapt to changing conditions, and at times it provided an answer to yesterday's challenges rather than today's. We conclude that the theory of polycentric governance needs to be developed further because it now lumps together too many different systems under the heading of polycentric governance. This calls for more longitudinal case studies on the development and effectiveness of individual polycentric governance systems within their changing context.
\end{abstract}

Key Words: adaptive management; drainage; flood management; island of IJsselmonde, Netherlands; petrification; polycentric governance; water resources management

\section{INTRODUCTION}

\section{Adaptation and polycentric governance}

One of the central tenets of adaptive management is polycentric governance. The term was introduced in 1961 by Ostrom et al. to refer to the existence of "many centers of decision-making which are formally independent of each other" (Ostrom et al. 1961:831). While originally introduced for describing the governance of metropolitan areas in the United States, the concept has since been used to analyze the management of common pool resources such as fisheries, groundwater resources, and irrigation systems (e.g., Ostrom 1990, McGinnis 1999, Andersson and Ostrom 2008, Neef 2009). Around the year 2000, the concept of polycentric governance was taken up by scholars in the field of adaptive management (e.g., Olsson and Folke 2001, Pahl-Wostl 2002). Among other things, it would facilitate experimentation and learning, reduce vulnerability, and promote adaptation to changing circumstances (e.g., Folke et al. 2005, Pahl-Wostl 2009).

Despite the popularity of the concept, few empirical tests of polycentric governance systems exist (Lieberman 2011). In this paper, we aim to provide such a test. We discuss the development of water management on the island of IJsselmonde (Fig. 1), near Rotterdam in the Netherlands, between the years 1000 and 1953, and then compare the results with the theory of polycentric governance. First, however, we present this theory. The two appendices offer snapshots of the water management system in the late eighteenth century and around 1920.
Fig. 1. Map of IJsselmonde in 1812 (van Alderwerelt 1812).

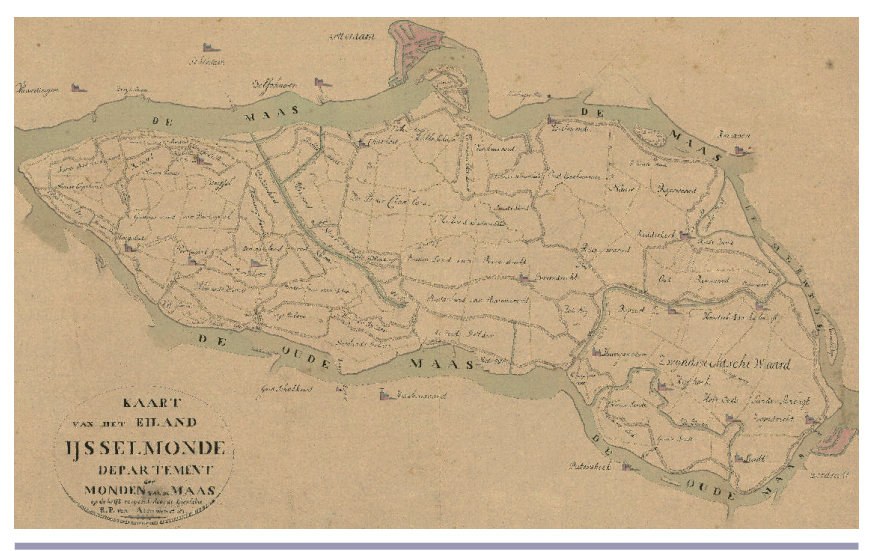

\section{Methods}

In practice, a qualitative-inductive approach was followed. The paper started out as a historical case study, but at the same time, the author was looking for a more general point of interest beyond the specific case. Polycentric governance presented itself as such because water management on IJsselmonde turned out to be extremely polycentric. Subsequently, a little literature study on polycentric governance theory was conducted and the case was compared with the theory.

For the historical case study, the author used a combination of literature study, archival research, and consultation of old maps. The literature study covered all published monographs 
on water management on IJsselmonde, published source material such as old charters, and general literature on the history of Dutch water management and governance (e.g., Schama 1977, Kaijser 2002, van der Ven 2004). Archival research focused on the period around 1800. For this, the polder archives kept in the Municipal Archive of Rotterdam and the Regional Archive Dordrecht were consulted. Moreover, large-scale topographical maps from around 1900 were consulted to better understand the historical situation (Schilder 2005). In addition, maps from the sixteenth to nineteenth centuries were consulted; these can be viewed online on the websites of the National Archive in The Hague and the Regional Archive Dordrecht, at http://www.gahetna.nl/ collectie/afbeeldingen/kaartencollectie and http://beeldbank.e rfgoedcentrumdiep.nl.

\section{A note on geographical names}

Throughout the paper, the geographical names "Holland" and "the Netherlands" are used a lot. To prevent confusion, it is important to note that the two are not synonymous. The Netherlands is the name of the present country. Holland is the name of the western part of the country, which since 1840 has consisted of two provinces, i.e., North-Holland and SouthHolland.

The name "IJsselmonde" referred originally only to the village of IJsselmonde and to the local jurisdictions of WestIJsselmonde and East-IJsselmonde. In the eighteenth century, the name was used for the central part of the island between the former sea branch "Koedood" in the west and the Zwijndrechtse waard in the southeast, where these two jurisdictions were located (Fig. 1, van Ollefen 1793). Only in the nineteenth century did the name IJsselmonde start to be used for the whole island. In this paper, "IJsselmonde" is used in the modern sense, referring to the whole island.

\section{POLYCENTRIC GOVERNANCE}

\section{Forms and shapes}

Polycentric governance as originally defined by Ostrom et al. (1961) covers very different governance systems. A good starting point for analyzing this diversity is the distinction made by Hooghe and Marks (2003) between Type I and Type II governance. Type I governance is the traditional decentralized state, with multipurpose jurisdictions at a limited number of government levels, e.g., national, provincial, and local. These jurisdictions are in principle mutually exclusive at their own level and perfectly nested within jurisdictions at the next higher level. Their boundaries usually correspond with communal identities, and accountability takes the form of direct elections, at least in the western world.

Type II governance is the type of governance that most authors think of when they talk about polycentric governance (see Ostrom et al. 1961). Type II governance is characterized by many task-specific jurisdictions, designed to address a limited set of related problems at the scale of these problems. Their number is in principle unlimited and they often overlap geographically and functionally.

Examples of Type II jurisdictions include clubs, agencies, and polity-forming jurisdictions (Skelcher 2005). Clubs are voluntary associations of individuals, groups, or member organizations with a common purpose. This could be the provision of a good or service, or the management of a common resource. Agencies are government creations, set up to increase effectiveness and efficiency by detaching service delivery from close political supervision and relaxing public sector regulations. Polity-forming jurisdictions are created to engage a public in policy through active participation, resulting in communities of place or interest. Electoral processes provide them with a mechanism to enable accountability and create new centers of legitimate collective political choice outside of Type I jurisdictions.

In practice, Type I and Type II jurisdictions may complement each other. For instance, some tasks may be allocated to specialized agencies while most are executed by traditional jurisdictions. Moreover, traditional jurisdictions may decide to form an intergovernmental commission-in fact a club.

How polycentric systems function depends crucially on the relations between the different jurisdictions. They may function independently from each other, but they may also compete with each other, conclude agreements, cooperate informally, or use different conflict-resolution mechanisms, such as court action and appeal to a higher administrative authority. To the extent that they function in a coherent manner and show consistent and predictable patterns of interacting behavior, they may be said to truly constitute a "system" (Ostrom et al. 1961:831).

\section{Potential effects}

The literature on polycentric governance mentions many potential benefits and drawbacks. First of all, polycentric governance would facilitate a better "fit" between the management scale and the scale of the issue to be managed. Related to this, local conditions and needs could be taken into account more easily than in more centralized systems. However, if there is too much decentralization, some issues may be managed at too low a level, and negative geographical externalities or "spillover effects" may occur (e.g., Ostrom et al. 1961, Newig and Fritsch 2009). Because the scale of issues can differ a lot and some issues play at several levels, arrangements will have to be made at several levels simultaneously. Hence, the call for multilevel governance (for example, Berkes 2006, Cash et al. 2006, Blomquist 2009, Brondizio et al. 2009, Termeer et al. 2010).

Secondly, polycentric governance would mean less bureaucracy and more possibilities for local involvement and local control. This would result in less corruption and lower 
costs (e.g., Ostrom et al. 1993). However, accountability and transparency may be problematic, especially in the case of Type II jurisdictions (Hooghe and Marks 2003, Skelcher 2005). In addition, local jurisdictions do not necessarily function effectively and democratically. They may be captured by specific interests and corruption may be rife. Moreover, it may be difficult for them to hire specialized personnel and economies of scale may be lost (e.g., Andersson and Ostrom 2008, Lieberman 2011).

Thirdly, polycentric governance would facilitate experimentation and learning. The different jurisdictions can try out different approaches and learn from each other's experiences. Communication lines are generally shorter and local knowledge can be used more easily. Yet, it may be harder to use scientific knowledge because of the difficulty of hiring experts (e.g., Hooghe and Marks 2003, Blomquist 2009).

Fourthly, there is usually a lot of overlap and redundancy in Type II systems. This makes the system as a whole less vulnerable because, if one center fails, others may take over their function. This in turn reduces the risk of experimentation and facilitates learning and adaptation. Yet, overlap and redundancy can also result in legal uncertainty, turf struggles, or free-riding on the efforts of others, or in double work (e.g., Andersson and Ostrom 2008, Blomquist 2009, Lieberman 2011).

Finally, several of the potential drawbacks mentioned above could be remedied or prevented by good cooperation and effective conflict resolution mechanisms. For instance, small municipalities sharing a resource could coordinate their policies to prevent spillover effects and together hire specialists that are otherwise too expensive for individual municipalities. But cooperation and conflict resolution mechanisms are not always effective, and transaction costs may be very high (Hooghe and Marks 2003, Huitema et al. 2009, M. D. McGinnis unpublished manuscript).

\section{IJSSELMONDE AND ITS GOVERNANCE}

\section{Development of the island}

IJsselmonde is a low-lying island of some 16,000 ha in the delta of the Rhine and Meuse rivers (Fig. 1); it is near, and partly in, Rotterdam. While currently highly urbanized, it was originally a sparsely populated area of fens and peat bogs.

Development of the island started around the year $1000 \mathrm{CE}$, when the first drainage works were undertaken (Henderikx 2001). The drainage works resulted in optimal conditions for agriculture, but they also initiated a cycle of land subsidence, land loss, and, eventually, land reclamation. Due to shrinkage and oxidization of the peat soils, the land subsided and conditions for agriculture gradually deteriorated. At the same time the costs for water management increased. When it was no longer economically feasible to maintain the dikes and sluices properly and repair them after a flood, the land drowned. As soon as this happened, however, the rivers and the sea started to deposit fresh layers of silt and clay on the drowned land, and after a shorter or longer time the land could be reclaimed and turned into fertile polders (van Dam 2003, cf. Leenders 2004). This involved the construction of a dike to protect the area from flooding and a drainage system to discharge excess rain water.

Land loss and land reclamation took place at different times. In the western part of the island, major land loss occurred in 1164 and reclamation started soon after 1180 (Hoek 1973). The southeastern part of IJsselmonde was flooded in 1321 and reclamation was completed by 1336 (Jorissen 1955, Duinker 1965). In the central part, supra-local supervision of the dikes was introduced in 1288, which may have postponed land loss; however, major land loss occurred in the 1370s (van Dam 2003). Reclamation started around 1400 and continued well into the nineteenth century.

\section{Feudal governance}

Drainage of fens and peat bogs originally required the consent of the sovereign, i.e., the king of Germany, who held all rights over all wildernesses. Around the year 1000, the count of Holland, the bishop of Utrecht, and other feudal lords started to exercise these rights instead of the king. At that time, IJsselmonde was contested by these lords, but the count of Holland won and from around 1200 onwards IJsselmonde formed an undisputed part of Holland (Henderikx 2001).

The western part of IJsselmonde formed part of the domain of Putten. Although the lord of Putten was a vassal of the count of Holland, the domain of Putten followed its own law and did not have to pay taxes to the count. In 1467, the count of Holland became lord of Putten himself, but Putten remained a separate district right until 1795 (Dekker and Kort 2004).

At the local level, the count of Holland or the lord of Putten was represented by the local reeve, who maintained order and presided over the local council. The local council consisted of two to seven councilors, who represented the local population but were appointed by the local reeve. These councils were essentially courts of law that could also issue bylaws. Penal cases were originally handled by the count or by the lord of Putten himself, together with their vassals. From the thirteenth century onwards cases were handled by regional officers of these lords, the bailiff of the district of South-Holland, and the warden of Putten, together with the vassals. In addition, these bodies could impose higher fines than the local councils and acted as courts of appeal (van der Ree-Scholtens and Spijkerman 1990).

In most local jurisdictions on IJsselmonde, the count of Holland had transferred the right to appoint the reeve and other local officers - the "local jurisdiction"-as a fief to one of his vassals. The vassal then became the local lord (or lady). The 
lord of Putten usually kept this right for himself, but between 1721 and 1742, all local jurisdictions in Holland that were not yet in private hands were sold to the highest bidder.

The local lord had special rights after a flood. If the land owners were not willing to repair the dike, the local lord could reclaim all rights concerning the land. In case there was no local lord or if the local lord was not willing to undertake the repairs, the count of Holland or the lord of Putten could reclaim the rights and give or sell these rights to others. (For more details see Beekman 1905-1907, Vol. 1:29-31).

\section{Revolutionary changes}

In the late sixteenth century, and between 1795 and 1848, important changes in the governance system took place. In the late sixteenth century, the inhabitants of Holland rebelled against the king of Spain, who had inherited the county of Holland. Together with six other provinces, Holland formed a loose federation, called the "Seven United Provinces". Within Holland, the Provincial States-representatives of the cities and a few members of the nobility - started to exercise the powers previously exercised by the count.

The changes between 1795 and 1848 were even larger. Around 1780 , the educated middle classes had started to demand more influence in government, which at the time was monopolized by the Prince of Orange and a limited number of patrician families, and on 17 January 1795, the Batavian revolution was proclaimed with the support of the French army. The Netherlands became a unitary state and all feudal rights were abolished, including the rights of the local lords (e.g., Schama 1977). By 1811, the Netherlands had become part of France and municipalities and independent courts were introduced (de Blécourt 1912). When the Netherlands regained its independence in 1813, the rights of the local lords were temporarily restored, but in 1848 the Netherlands got a liberal constitution and all feudal rights were abolished for good.

The constitution of 1848 introduced the governance system that in essence the country still has today: a parliamentary democracy with three government levels-national, provincial, and local. The lower levels have some autonomy, but they are also obliged to implement the policies of the higher levels and most of their funds come from the national government.

\section{LOCAL WATER MANAGEMENT}

\section{Before 1795}

The task of the local jurisdictions on IJsselmonde included water management. They regulated and oversaw the maintenance of the local infrastructure such as dikes, drainage canals, and sluices. The key instrument for this was the regular inspection by the reeve and the local councilors. Early in the year they would proclaim a bylaw describing the state that the different infrastructural works should be in, and twice or three times later in the year the state was checked. If the works were not in the correct state, the reeve could, with the consent of the councilors, contract the work to others and reclaim double the costs from the person or persons at fault (van Oudenhoven 1654:496, 512; Henderikx 2001; van Alkemade and van der Schelling, date unknown b:26-33).

Maintenance of the infrastructure was the responsibility of the land users, mostly tenant farmers. Originally, tracts of dike were allotted to individual plots of land, but gradually maintenance was contracted out and a polder charge per hectare was introduced to fund this. In some polders this change took place as early as 1462 (van Alkemade and van der Schelling, date unknown a: fol. 6), but in others individual maintenance was the rule until 1862 (Jorissen 1955). In newer polders (e.g., the Binnenpolder of 1483) common maintenance was the rule from the start (van Oudenhoven 1654:277-279). Common maintenance was also the rule for more complex infrastructure, such as polder mills, which were introduced on IJsselmonde in the late fifteenth century (Wouda 2009). Exceptional expenses, e.g., for the replacement of a sluice, were paid for by the land owners and not the land users (van Alkemade and van der Schelling, date unknown b:105-106, Hordijk 1983).

During land reclamation, often it was not economical to stick to jurisdictional boundaries. Consequently, many polders were located in more than one jurisdiction and many local jurisdictions contained more than one polder. In these cases, the land users and owners had to pay for the works in their own polder only, but regulation and supervision remained at the level of the local jurisdiction or jurisdictions. In case of a polder located in more than one jurisdiction, the polder works would be inspected by a council with representatives from all the jurisdictions, but the council would be presided over by the reeve of the local jurisdiction in which the specific polder work was located (e.g., in the Binnenpolder mentioned above).

The result of this system was that two types of local water management entities existed side by side: the local jurisdictions and communities of land users and owners in the individual polders. In the late eighteenth century, there were no fewer than 31 local jurisdictions and 65 polders on the island (Appendix 1). To complicate the picture, in several local jurisdictions there were separate dike reeves ("dijkgraven") and councilors for public works, either for all polders within the local jurisdiction or for individual polders. In one jurisdiction (Charlois) there were even two different dike reeves, one for the dikes and one for the internal drainage works and roads.

\section{After 1795}

The social and political changes in the period 1795 to 1848 had a profound impact on local water management. On 6 March 1795, the "provisional representatives of the people of 
Holland" decided that, for the time being, the different local water management organizations had to remain in place, but on 7 October they decided that individual board members could be replaced and that from then on board members should be elected by those who had to pay the polder charges or maintain the water management infrastructure (Röell 1866). Subsequently, the land owners and users in some polders decided to elect their own polder board (e.g., in Barendrecht and Charlois). These polder boards then took over the water management tasks from the local jurisdictions.

When municipalities were introduced in 1811, the old local jurisdictions continued to exist as water management organizations, at least where their tasks had not been taken over completely by the polders (de Blécourt 1912). In 1813 the rights of the local lords were restored, but not completely: in polders with sea defenses, dike reeves and councilors were to be appointed by the king and the local lord could only nominate a candidate. In 1848 they lost even this right.

The constitution of 1814 gave the provinces the right to change the statutes of the different water management organizations. Originally, it was not clear whether the provinces could also merge these organizations (Thorbecke 1843, Korf 1977), but the constitutions of 1848 and, especially, of 1887 made clear that they could. Despite its competence in this field, the province of South-Holland, in which IJsselmonde is located, has always been very reluctant to impose reorganization. Yet, in 1856 the province made a general polder bylaw. This bylaw effectively abolished the old jurisdictions and entrusted local water management to polder boards, under the supervision of the province. The board members were to be elected by the land owners in the polder-i.e., farmers owning their own land and absentee landowners-who also funded the polder board in proportion to their land holdings. Initially, every hectare owned meant one vote, with a maximum of $25 \%$ of all votes in the polder, but in 1917 a far more regressive scale was introduced, giving more influence to small landholdings.

In the nineteenth century, polders were often seen as associations of land with a common interest, represented by the land owners, and hence quite different from municipalities, provinces, and the state (Plemp van Duiveland 1893). This had two consequences. First, while before 1795 the land users in some polders had the right to elect their treasurer, under the new polder bylaw they lost all voting rights. This fitted in very well in and may be explained by the liberal ideology at the time and the role it gave to private property. Secondly, minors and married women could not vote for the municipal and provincial council nor for parliament, but they did have voting rights for polder boards if they owned land. However, their voting rights had to be exercised by a male guardian, such as a husband or a father. From 1913 onwards, they could vote in person if they were of age and not married or if by means of a marriage settlement they had retained the right to manage their own property. This last change provides another example of how broad social and political changes are reflected in water management.

\section{CENTRALIZATION IN FLOOD PROTECTION}

\section{Before 1795}

While most water management on IJsselmonde was organized locally, in some parts supra-local dike management was introduced. In 1288, Count Floris V of Holland declared that if a dike of the Riederwaard, i.e., the central part of IJsselmonde, broke, the repairs would be done by the whole of the Riederwaard, irrespective of the local jurisdiction in which the dike was located, provided the dike had been inspected and found to be in good order. This introduced risk sharing among the local jurisdictions in the Riederwaard, as well as regional dike inspection (Henderikx 2001:196). The regional dike inspections were initially conducted by representatives of the different local jurisdictions under the direction of the count's bailiff, but later a separate dike bailiff was appointed (van Dam 2003:31, van Oudenhoven 1654:473). When the Riederwaard was flooded in the 1370s, regional dike inspection disappeared and it was not revived when the Riederwaard was reclaimed from 1400 onwards. The only, partial, exception was the joint inspection of the dikes in Ridderkerk and Oost-IJsselmonde, based on an agreement of 21 May 1446 between these two jurisdictions (van Oudenhoven 1654:268-270).

Concerning the drowned Zwijndrechtse Waard, the count declared in 1332 that persons participating in the reclamation works for one-sixteenth part or more would become the local lord for their part. All local lords together would appoint a dike bailiff, who would inspect the dikes together with his councilors. This system lasted well until the nineteenth century (van Oudenhoven 1654:240-241, Jorissen 1955).

In the western part of IJsselmonde, mention is made of a dike reeve in 1379 (van der Gouw 1980, Vol. 1:28). In later centuries, the Common Land of Poortugaal water board covered three local jurisdictions, but not completely. Newer polders created in front of the old land after the establishment of the water board were not brought under the jurisdiction of the water board (see Appendix 1). Hence, the water board did not inspect the dikes of the new polders, even though these dikes also protected the old polders.

\section{Dike Act of 1810}

On 31 January 1810, an innovative Dike Act was adopted. The purposes of the Dike Act, according to the responsible minister, were to improve dike maintenance without changing the distribution of costs too much and to reduce the need for state subsidies (Maas 1963:33-35). The different polders in the Netherlands were combined into seventeen dike ring areas, one being IJsselmonde, and for each dike ring area a small commission was appointed. This commission would inspect 
the dikes twice a year and could give binding orders to the different polders responsible for dike management. If the costs for a specific polder exceeded a certain maximum, first an extraordinary polder charge would have to be imposed on all land in the polder, including the lands that under normal circumstances were exempted. If this charge did not yield enough, a dike ring charge would have to be imposed on all land in the dike ring area, up to a maximum of one-third of the total rental value of the land (including the ordinary and the extraordinary polder charges). If this still did not yield enough, state subsidies could be given.

The ring commission for IJsselmonde was very active. On 6 June 1811, it ordered the raising of several dikes, especially in the western part of the island. To finance the works, a dike ring charge would be necessary. This was not appreciated in the Zwijndrechtse Waard, where the dikes had already been raised in 1808 and no new works were necessary. Nor were the activities of the ring commission welcome in the western part of IJsselmonde. According to Hendrik Johsz. Vermaat, a local farmer, the whole affair was

the most unnatural thing that ever occurred in our country. A ring commission came from the city of Dordrecht and the farmers were ordered to raise the dikes, whether it was necessary or not. And these were gentlemen that did not have to pay a farthing because they did not own a square inch of land. But there was no arguing against them.

(translated by the author of this paper, from Vermaat and Vermaat 1997:36; cf. Beschouwing van de dijkbesturen ... 1839)

For financial reasons and because of the difficult economic situation, the raising of several dikes was cancelled in 1812, and in 1814 all the ring commissions stopped functioning.

\section{Decentralization and recentralization}

New attempts to centralize dike management were made in 1851. In reaction to draft provincial statutes for the polder Nieuw-Reijerwaard, a number of land owners in that polder sent a letter to the provincial executive asking whether it would not be better to establish regional dike management. The provincial executive consulted the polder boards on the island - not the individual land owners-about this issue, but all were against because they saw the plans as an infringement on their rights and a threat to their independence. The province tried again in 1860, but the result was the same (Inventaris van het archief van het Waterschap De Oude . . . date unknown).

Some degree of centralization was introduced following the storm surge of 23 December 1894. The dikes of two polders in the western part of the island had been damaged, and it was not considered fair that only these two polders would bear the costs of the repairs: the other polders protected by these dikes should contribute as well. Subsequently, two new water boards were established, dealing exclusively with flood protection: a water board for the west dikes of IJsselmonde, and a water board the old and new dikes in front of Rhoon.

Following the flooding of the Zuidpolder, in 1928, the province used the opportunity to propose the establishment of one water board for the management of all dikes of IJsselmonde. The Rhoon water board was against this. They had lost a lot of territory to the expanding harbor of Rotterdam and therefore proposed a merger with the adjacent west dikes of IJsselmonde water board. Dike management on the remainder of the island could be done by two water boards. According to the Rhoon water board, one water board for all the dikes on the island would be more expensive because more and higher qualified officials would have to be hired (Inventaris van het archief van het Waterschap De Oude... date unknown).

One water board for all the dikes was created only after the largest flood in the Netherlands in living memory, i.e., the flood disaster of 1 February 1953. On 1 January 1955, the water board for the dike ring of IJsselmonde was established, but not without much discussion. In 1973, this water board merged with the different polders on IJsselmonde, and was renamed the IJsselmonde Water Board. On 1 January 2005, this water board in turn merged with three adjacent water boards and a water purification board to form the Hollandse Delta Water Board.

\section{UPSCALING OF DRAINAGE}

\section{Drainage problems}

While flood protection was the main issue triggering centralization, some upscaling in drainage management took place as well. When a new polder was created in front of an old one that drained directly onto the river, these two polders had to agree on the construction and maintenance of a new drainage canal through the new polder and a sluice in the new dike. The resulting arrangements could become very complex (e.g., Teixeira de Mattos 1920:286-290).

In the case of the Koedood, the drainage arrangements concerned an area of some 2300 ha. The Koedood was a sea arm that was formed after the drowning of the Riederwaard in the 1370s. When the Koedood was closed off in 1580, a solution had to be found for eight polders draining onto the Koedood. The solution involved the construction of a new drainage canal and two new sluices. The Koedood and the connected works were managed by a committee of representatives of the eight polders, on the basis of contracts.

In 1842, one of the eight polders-polder Binnenland van Barendrecht-raised its embankment along the Koedood, allowing it to discharge drainage water onto the Koedood long after the agreed upon maximum water level in the Koedood 
had been reached. This caused problems for the other polders. However, there was nothing in the existing contracts that required the polder Binnenland to observe the maximum water level. A solution could only be found in 1870 , when a new agreement was necessary on the construction of a steam pumping station that would serve all eight polders. Nine years later, in 1879, the committee for managing the Koedood was changed into a regular water board with the power to make binding regulations (Inventaris van het archief van Waterschap De Koedood, date unknown).

\section{Windmills and pumping stations}

Individual polders often cooperated on the establishment of a wind mill or a steam pumping station. For smaller polders it often was not economical to have their own wind mill and especially not their own pumping station.

Cooperation could take different forms: a contract between the polders concerned, the establishment of a new water board exclusively for the operation of the pumping station, or a merger of the polders concerned (Appendices 1 and 2). Each form had its advantages and disadvantages. Contracts could be concluded without involving any higher authority, but the resulting arrangements lacked any public power, and any change required difficult negotiations. New water boards could result in competency problems with the old polders and could complicate management (Hordijk 1983). Merging polders could be problematic because of the different financial situations of the polders and hence the polder charges often differed a lot. For instance, some polders had a relatively large amount of dike to maintain, while others owned a lot of income-generating real estate (see Wouda 2004).

A solution for the different financial situations was to keep different accounts for the common works and for the different polders, and to differentiate the polder charge. However, there could be other obstacles for mergers as well, such as attachment to independence and personal considerations. Obviously, when two polders merge, one of the two chair persons becomes redundant. This may have been behind polder Ziedewij's opposition to a proposed merger with the polder Binnenland van Barendrecht in 1941. Seven years later, the two polders had the same chair person and opposition had disappeared (Hordijk 1983).

\section{DISCUSSION}

\section{Shapes and forms}

Water management on IJsselmonde until 1953 provides an example of a very polycentric governance system. This example shows, first of all, that polycentric institutions are even more varied than the typologies that Hooghe and Marks (2003) and Skelcher (2005) suggest. The different polder boards on IJsselmonde could count as examples of polityforming institutions, except that the boards were not established to create a polity, but to organize an existing community of interests. Moreover, the different polder boards often cooperated with each other, but not only in the form of voluntary associations or "clubs". In fact, they could use a whole array of institutional forms, ranging from informal cooperation to contracts, clubs, and even partial or complete mergers. And cooperation was not always completely voluntary: the province had the legal power to reorganize the polders, even if it was reluctant to use this power.

With respect to the Type I jurisdictions on IJsselmonde discussed in this paper-i.e., the local jurisdictions-it may be interesting to note that they did not always coincide with communal identities. Some contained only a few farmsteads, and a few were split in two after a river changed its course, without any adjustment of their boundaries (e.g., Alblasserdam).

\section{Effects}

Water management on IJsselmonde offers several illustrations of the potential advantages of polycentric governance. The polycentric governance system made it possible to match the management scale with the scale of the management issue concerned, if necessary by establishing a new organization. Moreover, it made it possible to involve local beneficiaries in decision-making and financing, thus reducing costs and limiting the risk of wasteful projects. There is also some circumstantial evidence that polycentric governance was less bureaucratic than centralized governance: around 1800, and especially under French occupation, more centralization was introduced and the amount of paperwork increased dramatically (cf. de Blécourt 1912).

Direct evidence of more experimentation and learning is limited, but we can point to an experimental pumping station in 1904 (Ten Horn-van Nispen 2003). Moreover, detailed research on polder technologies in three polders on the mainland of Holland has shown that polders sometimes did try out new technologies and that knowledge of these new technologies did circulate (Zeischka 2007).

The main disadvantage of the water management system was that regional issues, in particular dike management, were not always handled at the regional level. Consequently, management did not always involve all beneficiaries. This may have resulted in underinvestment and unnecessary flooding.

Secondly, until the mid nineteenth century, water management could not really be called democratic because most officials were appointed and not elected. The same can be said of most other Dutch water management organizations at the time (for example, Dolk 1939, Fockema Andreae 1952, van der Ham and Jacobs 2004, van Tielhof and van Dam 2006). Hence, it is not correct to call the Dutch water boards the "oldest democratic institutions" in the Netherlands (e.g., Lazaroms and Poos 2004, Dicke and Albrow 2005, van Stokkom et al. 2005, Huisman 2007). 


\section{Adaptation and petrification}

Polycentric governance is often posited as facilitating adaptation to changing conditions and new insights (e.g., Folke and Hahn 2005, Pahl-Wostl 2009). However, relatively little has been written about the issue of how adaptive polycentric governance systems themselves are.

If we look at IJsselmonde, we can see a lot of change, but this was over the course of nearly a thousand years. In fact, change was often slow and difficult. At times, the water management system even became "petrified": arrangements made under one set of conditions to face the challenges at the time sometimes persisted for a long time after conditions had changed. Perhaps the clearest example of petrification is the Common Land of Poortugaal water board. When this water board was established, it secured a good fit between the management scale and the scale of the issue concernedregional flooding problems were handled at the regional level - but this fit was lost as new polders were created in front of the old ones that were not brought under the jurisdiction of the water board.

Several factors may explain why change was often so difficult. First of all, we can mention vested interests. Introduction of regional dike management was often opposed by those whose land in the present situation did not have to contribute to dike management, with these people often arguing that they had bought the land more dearly because of this (Beschouwing van de dijkbesturen . . . 1839). Within individual polders the introduction of common dike maintenance instead of individual maintenance sometimes led to similar conflicts of interest (van Alkemade and van der Schelling, date unknown a: fol. 6).

Secondly, a higher authority capable of and willing to lead change processes was often lacking (cf. Olsson et al. 2006, Meijerink and Huitema 2009). Higher authorities can help parties to reach agreement and decide for the parties if they cannot reach agreement. Moreover, using their formal powers, they can give extra strength to agreements, improve control and enforcement, and establish new special-purpose organizations to implement agreements (cf. the SouthernCalifornian groundwater management case discussed in Ostrom 1990). But especially in the seventeenth and eighteenth centuries, capable and willing higher authorities were absent on IJsselmonde. In this period local rights were cherished and there was little innovation in water governance. In the nineteenth century, the province of South-Holland got all the legal powers it needed to reorganize local water management. The province supported polders that wanted to merge or set up a new water board, but, unlike some other provinces, South-Holland was not willing to impose major reorganization (Fockema Andreae 1952, Moorman van Kappen et al. 1977). Without further research, we cannot tell whether this was out of respect for local autonomy and acquired "rights", because of the influence of vested interests, or because of another reason.

Thirdly, change is simply very complex. Especially Type II polycentric systems such as on IJsselmonde can be very complex. Changing such systems from the outside can have many unforeseen consequences. A lot of information is needed about the current arrangements but often the only people who have all this information are those who are personally involved and who may have vested interests in the current situation.

Fourthly, several "soft" factors should be mentioned, such as personal prestige and emotional attachment to old institutions. These factors may explain why in 1851 and 1860 even polders that had much dike to maintain and would benefit financially were against the introduction of regional dike management. Moreover, soft factors may explain why many mergers of polders were initially opposed, such as the merger of the polders Ziedewij and Binnenland van Barendrecht discussed above.

If we now turn our attention to the factors that may explain change, three factors stand out: (financial) compensation, broad social and political changes, and (flood) disasters. Many agreements that involved changing the management arrangements also involved compensation of those who would stand to lose out, e.g., in the form of a lower tariff for the polder charges. But the overall shape of the arrangements clearly bore the imprint of, and changed with, the structure of society and government. To give just one example: the introduction of voting rights for women for the polder boards had nothing to do with water management but everything to do with broader social and political developments taking place at the time. In addition, large changes were often made after flood disasters (cf. Mostert 2009). The most likely explanation for this is that disasters increase the urgency of reform and may help to overcome resistance to change.

We cannot conclude on the basis of only one case study that polycentric systems are less adaptive than more centralized systems. However, we can conclude that adaptiveness may be problematic. Moreover, two of the four factors explaining the difficulty of change may be especially prominent in polycentric systems: absence of a higher authority that is both capable and willing to take the lead, and complexity of change.

\section{CONCLUSION AND OUTLOOK}

While there is evidence that polycentric governance can have positive effects, it is still too early to use polycentricity normatively for evaluating existing governance systems, or designing new ones. The main reason is not that polycentricity may have negative effects as well, such as petrification, although these should not be ignored. The main reason is that the theory of polycentric governance has not yet developed enough. All governance systems are polycentric to some extent, but the number and type of decision-making centers 
and their interrelations can differ a lot. Hence, conclusions concerning one type of polycentric governance may not necessarily hold for other types of polycentric governance.

Despite this limitation, the concept of polycentric governance may prove to be an asset for future research. Polycentric governance covers or touches upon many themes and theories that too often are discussed separately, but in fact are related or even overlapping. These include adaptive management, decentralization, scale, institutional fit and interplay, social learning, network management, and collaboration theory (Gray 1989, Klijn and Koppenjan 2000, Bouwen and Taillieu 2004, Huxham and Vangen 2005, Klijn and Koppenjan 2006, Mostert et al. 2007, Muro 2008, Young 2008). Because of its broadness, the concept of polycentric governance may be used as an antidote against partial and parochial analyses.

That being said, there is a big need for more in-depth case studies of individual polycentric governance systems. These should not only study the systems themselves and how they function at any given point in time, but also under what conditions they function (cf. Edwards and Steins 1999) and whether and how they adapt themselves to changing conditions. In each new case study, the ideas developed before can be tested and then modified or complemented. In this way, a more differentiated empirical theory of polycentric governance can be built up. Of course, reality will always be more varied and complex than any theory, but a good theory can provide us with the tools for analyzing, understanding, and managing this complexity.

Responses to this article can be read online at: http://www.ecologyandsociety.org/vol17/iss3/art12/ responses/

\section{LITERATURE CITED}

Andersson, K., and E. Ostrom. 2008. Analyzing decentralized resource regimes from a polycentric perspective. Policy Sciences 41(1):71-93. http://dx.doi.org/10.1007/s11077-0079055-6

Beschouwing van de dijkbesturen en hoogheemraadschappen in derzelven oorsprong, ontwikkeling en voortduring. 1839. Van der Meer \& Verbruggen, Rotterdam.

Beekman, A. A. 1905-1907. Het Dijk- en Waterschapsrecht in Nederland voor 1795. Martinus Nijhoff, 's-Gravenhage.

Berkes, F. 2006. From community-based resource management to complex systems: the scale issue and marine commons. Ecology and Society 11(1):45. [online] URL: http: //www.ecologyandsociety.org/vol11/iss1/art45/.

Blomquist, W. 2009. Multi-level governance and natural resource management: the challenges of complexity, diversity, and uncertainty. Pages 109-126 in V. Beckmann and
M. Padmanabhan, editors. Institutions and sustainability; essays in honour of Konrad Hagedorn. Springer, s.l. http://dx .doi.org/10.1007/978-1-4020-9690-7 6

Bouwen, R., and T. Taillieu. 2004. Multiparty collaboration as social learning for interdependence: developing relational knowledge for sustainable natural resources management. Journal of Community and Applied Social Psychology 14 (3):137-153.

Brondizio, E. S., E. Ostrom, and O. R. Young. 2009. Connectivity and the governance of multilevel socialecological systems: the role of social capital. Annual Review of Environment and Resources 34:253-278. http://dx.doi.org/ 10.1146/annurev.environ.020708.100707

Cash, D. W., W. N. Adger, F. Berkes, P. Garden, L. Lebel, P. Olsson, L. Pritchard, and O. Young. 2006. Scale and crossscale dynamics: governance and information in a multilevel world. Ecology and Society 11(2):8. [online] URL: http://ww w.ecologyandsociety.org/vol11/iss2/art8/.

de Blécourt, A. 1912. Ambacht en gemeente. De regeering van een Hollandsch dorp gedurende de 17e, 18e en 19e eeuw. Wansleven, Zutphen.

Dekker, C., and J. C. Kort. 2004. Inventaris van het archief van de Heren van Putten en Strijen, 1235-1459. Nationaal Archief, Den Haag. [online] URL: http://www.gahetna.nl/col lectie/archief/pdf/NL-HaNA 3.19.43.ead.pdf.

Dicke, W., and M. Albrow. 2005. Reconstituting the publicprivate divide under global conditions. Global Social Policy 5:227. http://dx.doi.org/10.1177/1468018105053680

Dolk, T. F. J. A. 1939. Geschiedenis van het hoogheemraadschap Delfland. Nijhoff, 's-Gravenhage.

Duinker, P. F. 1965. Inventaris van het archief van de Develpolder. Provinciale inspectie van de gemeente- en waterschapsarchieven in Zuid-Holland, Den Haag.[online] URL: http://www.gahetna.nl/collectie/archief/pdf/NLHaNA 3.03.08.222.ead.pdf.

Edwards, V., and N. Steins. 1999. A framework for analysing contextual factors in common pool resource research. Journal of Environmental Policy \& Planning 1(3):205-221.

Fockema Andreae, S. J. 1952. Studien over waterschapsgeschiedenis. Dl. 8. Overzicht van de Nederlandse Waterschapsgeschiedenis. Brill, Leiden.

Folke, C., T. Hahn, P. Olsson, and J. Norberg. 2005. Adaptive governance of social-ecological systems. Annual Review of Environment and Resources 30:441-473. http://dx.doi.org/10 .1146/annurev.energy.30.050504.144511

Gray, B. 1989. Collaborating: finding common ground for multiparty problems. Jossey-Bass, San Francisco, California, USA. 
Henderikx, P. A. 2001. Land, water en bewoning: Waterstaatsen nederzettingsgeschiedenis in de Zeeuwse en Hollandse delta in de Middeleeuwen. Verloren, Hilversum.

Hoek, C. 1973. Pernis zonder olie. Holland; RegionaalHistorisch Tijdschrift 5:181-195.

Hooghe, L., and G. Marks. 2003. Unraveling the central state, but how? Types of multi-level governance. The American Political Science Review 97(2):233-243.

Hordijk, L. W. 1983. Inventaris van de archieven van de polder Binnenland en Ziedewij. Waterschap IJsselmonde, Brielle. [online] URL: http://www.archieven.nl/nl/zoeken?mivast=0\& mizig $=210 \&$ miadt $=184 \&$ micode $=1342 \&$ miview=inv 2 .

Huisman, P. 2007. How the Netherlands finance public water management. European Water Management Online. [online] URL: http://www.ewaonline.de/journal/2002 031.pdf.

Huitema, D., E. Mostert, W. Egas, S. Moellenkamp, C. PahlWostl, and R. Yalcin. 2009. Adaptive water governance: assessing adaptive management from an institutional perspective. Ecology and Society 14(1):26. [online] URL: http://www.ecologyandsociety.org/vol14/iss1/art26/.

Huxham, C., and S. Vangen. 2005. Managing to collaborate: the theory and practice of collaborative advantage. Routledge, London, New York, New York, USA.

Inventaris van het archief van het Waterschap De Oude en Nieuwe Maasdijken voor het Land van Rhoon. [date unknown]. [online] URL: http://www.archieven.nl/nl/zoeken? mivast $=0 \&$ mizig $=210 \&$ miadt $=184 \&$ micode $=1355 \&$ miview $=$ inv2/.

Inventaris van het archief van Waterschap De Koedood. [date unknown]. [online] URL: http://www.archieven.n1/n1/zoeken? mivast $=0 \&$ mizig $=210 \&$ miadt $=184 \&$ micode $=1346 \&$ miview $=$ inv2l.

Jorissen, F. 1955. Het Hoogheemraadschap van de Zwijndrechtse Waard; Februari 1331-Februari 1955. Hendrik-Ido-Ambacht.

Kaijser, A. 2002. System building from below: institutional change in Dutch water control systems. Technology and Culture 43(3):521-548. http://dx.doi.org/10.1353/tech.2002.0120

Klijn, E.-H., and J. F. M. Koppenjan. 2000. Public management and policy networks: foundations of a network approach to governance. Public Management 2(2):135-158. http://dx.doi.org/10.1080/146166700411201

Klijn, E.-H., and J. F. M. Koppenjan. 2006. Institutional design: changing institutional features of networks. Public Management Review 8(1):141-160.

Korf, J. 1977. Chapter 1 in O. Moorman van Kappen, J. Korf, and O. W. A. v. Verschuer, editors. Tieler- en
Bommelerwaarden 1327-1977: grepen uit de geschiedenis van 650 jaar waterstaatszorg in Tielerwaard en Bommelerwaard. Tiel-Zaltbommel.

Lazaroms, R., and D. Poos. 2004. The Dutch water board model. Journal of Water Law 15(3-4):137-140.

Leenders, K. A. H. W. 2004. De interactie tussen mens en natuur in de strijd om land en water in het zuiden van Holland, 1200-1650. Holland; Regionaal-Historisch Tijdschrift 36:142-161.

Lieberman, E. S. 2011. The perils of polycentric governance of infectious disease in South Africa. Social Science \& Medicine 73(5):676-684. http://dx.doi.org/10.1016/j.socscim ed.2011.06.012

Maas, W. J. M. 1963. De Dijkwet van 1810: een algemene bijdragenwet in de Franse tijd. Nijgh \& Van Ditmar, Rotterdam/'s-Gravenhage.

McGinnis, M. D. 1999. Polycentric governance and development: readings from the Workshop in Political Theory and Policy Analysis. University of Michigan Press, Ann Arbor, Michigan, USA.

Meijerink, S., and D. Huitema. 2009. Understanding and managing water policy transitions: a policy sciences perspective. Pages 23-36 in D. Huitema, and S. Meijerink, editors. Water policy entrepreneurs: a research companion to water transitions around the globe. Edward Elgar, Northhampton, Massachusetts, USA.

Moorman van Kappen, O., Korf, J., and Van Verschuer, O. W. A. 1977. Tieler-en Bommelerwaarden 1327-1977: grepen uit de geschiedenis van 650 jaar waterstaatszorg in Tielerwaard en Bommelerwaard. Tiel-Zaltbommel.

Mostert, E. 2009. International cooperation on Rhine water quality 1945-2008: an example to follow? Physics and Chemistry of the Earth 34(3):142-149.

Mostert, E., C. Pahl-Wostl, Y. Rees, B. Searle, D. Tàbara, and J. Tippett. 2007. Social learning in European river basin management: barriers and supportive mechanisms from 10 river basins. Ecology and Society 12(1):19. [online] URL: http://www.ecologyandsociety.org/vol12/iss1/art19/.

Muro, M. 2008. A critical review of the theory and application of social learning in participatory natural resource management processes. Journal of Environmental Planning and Management 51(3):325-344. http://dx.doi.org/10.1080/0 $\underline{9640560801977190}$

Neef, A. 2009. Transforming rural water governance: towards deliberative and polycentric models. Water Alternatives 2 (1):53-60. 
Newig, J., and O. Fritsch. 2009. Environmental governance: participatory, multi-level - and effective? Environmental Policy and Governance 19(3):197-214.

Olsson, P., and C. Folke. 2001. Local ecological knowledge and institutional dynamics for ecosystem management: a study of Lake Racken watershed, Sweden. Ecosystems 4(2):85-104. http://dx.doi.org/10.1007/s100210000061

Olsson, P., L. H. Gunderson, S. R. Carpenter, R. P., L. Lebel, C. Folke, and C. S. Holling. 2006. Shooting the rapids: navigating transitions to adaptive governance of socialecological systems. Ecology and Society 11(1):18. [online] URL: http://www.ecologyandsociety.org/vol11/iss1/art18/.

Ostrom, E. 1990. Governing the commons: the evolution of institutions for collective action. Cambridge University Press, Cambridge, New York, USA.

Ostrom, E., L. D. Schroeder, and S. G. Wynne. 1993. Institutional incentives and sustainable development: infrastructure policies in perspective. Westview Press, Boulder, Colorado, USA, and Oxford, UK.

Ostrom, V., C. M. Tiebout, and R. Warren. 1961. The organization of government in metropolitan areas: a theoretical inquiry. The American Political Science Review 55 (4):831-842. http://dx.doi.org/10.2307/1952530

Pahl-Wostl, C. 2002. Towards sustainability in the water sector-the importance of human actors and processes of social learning. Aquatic Sciences - Research Across Boundaries 64(4):394-411.

Pahl-Wostl, C. 2009. A conceptual framework for analysing adaptive capacity and multi-level learning processes in resource governance regimes. Global Environmental Change 19(3):354-365. http://dx.doi.org/10.1016/j.gloenvcha.2009.06.001

Plemp van Duiveland, L. J. 1893. Het Waterschap tegenover zijne schuldeischers. P. Somerwil, Leiden.

Röell, J. 1866. Historisch-staatsregtelijk onderzoek naar het algemeen en het bijzonder bestuur van den waterstaat in Nederland van 1795-1848. J. de Kruyf, Utrecht.

Schama, S. 1977. Patriots and liberators: revolution in the Netherlands, 1780-1813. Knopf, New York, New York, USA.

Schilder, E., editor. 2005. Grote historische topografische atlas 1:25.000. Zuid-Holland \pm 1905 . Nieuwland, Tilburg.

Skelcher, C. 2005. Jurisdictional integrity, polycentrism, and the design of democratic governance. Governance: An International Journal of Policy, Administration, and Institutions 18(1):89-110. http://dx.doi.org/10.1111/j.1468-04 91.2004.00267.x
Teixeira de Mattos, L. F. 1920. De waterkeeringen, waterschappen en polders van Zuid-Holland. Dl. 6. De eilanden (vervolg). Afd. 2. Het eiland IJsselmonde. Nijhoff, 's-Gravenhage. http://dx.doi.org/10.1007/978-94-015-3008-8

Ten Horn-van Nispen, M.-L. 2003. Nieuwe technologie in een oude polder; het zuiggasgemaal van Oud-Reijerwaard. Pages 159-175 in B. Wouda, editor. Ingelanden als uitbaters: sociaal-economische studies naar Oud- en NieuwReijerwaard, een polder op een Zuid-Hollands eiland. Verloren, Hilversum.

Termeer, C. J. A. M., A. Dewulf, and M. van Lieshout. 2010. Disentangling scale approaches in governance research: comparing monocentric, multilevel, and adaptive governance. Ecology and Society 15(4):29. [online] URL: http://www.eco logyandsociety.org/vol15/iss4/art29/.

Thorbecke, J. R. 1843. Brief aan een lid der Staten van Gelderland, over de magt der Provinciale Staten uit Art. 220 der Grondwet. P. H. van den Heuvell, Leiden.

van Alderwerelt, R. P. 1812. Kaart van het eiland IJsselmonde. Departement van de Monden van de Maas. Manuscript, Netherlands National Archive, The Hague. Kaartcollectie Zuid-Holland Ernsting, toegang 4.ZHPB4, inv. nr. 121.

van Alkemade, K., and P. van der Schelling. [date unknown a]. Privilegiën van de overmaase landen: manuscript. Municipal Archive Rotterdam, Handschriftenverzameling (aanvullingen 1988 t/m 1998), inv. nr. 9184.

van Alkemade, K., and P. van der Schelling. [date unknown b]. Octrooien, privilegiën, ordonnantien en keuren van de lande van Putten en de stad Geervliet: manuscript. Municipal Archive Rotterdam, Handschriftenverzameling, inv. nr. 1760.

van Dam, P. J. E. M. 2003. Schijven en beuken balken: een sociaal-ecologische transformatie in de Riederwaard. Pages 11-43 in B. Wouda, editor. Ingelanden als uitbaters; Sociaaleconomische studies naar Oud-en Nieuw-Reijerwaard, een polder op een Zuid-Hollands eiland. Verloren, Hilversum.

van der Gouw, J. L., editor. 1980. Rekeningen van de domeinen van Putten 1379-1429. Martinus Nijhoff, 's-Gravenhage.

van der Ham, W., and I. Jacobs, editors. 2004. Hoge dijken, diepe gronden. Land en water tussen Rotterdam en Gouda: een geschiedenis van Schieland. Matrijs, Utrecht.

van der Ree-Scholtens, G. F., and H. Spijkerman. 1990. Inventaris van het archief van de Baljuw en Hoge Vierschaar van Zuid-Holland, 1574-1811 (1813). Nationaal Archief, Den Haag. [online] URL: http://www.gahetna.nl/collectie/archief/ ead/index/eadid/3.03.08.224. 
van Ollefen, L. 1793. De Nederlandsche stad- en dorpbeschrijver; I. deel. 't Eiland van Dordrecht, de Hoeksche waard, de Zwijndrechtse waard, en 't Land van IJsselmonde. H.A. Banse, Amsterdam.

van der Ven, G. P., editor. 2004. Man-made lowlands history of water management and land reclamation in the Netherlands. Fourth edition. Matrijs, Utrecht, Netherlands.

van Oudenhoven, J. 1654. Out-Hollandt, nu: Zuyt-Hollandt, vervangende een generale beschrijvinge, mitsgaders de privilegien, keuren, hant-vesten, costuymen, herkomens, observantien ende gewijsdens van de voorsz. landen. Abraham Andriessz., Dordrecht.

van Tielhof, M., and P. J. E. M. van Dam. 2006. Waterstaat in stedenland: het hoogheemraadschap van Rijnland voor 1857. Matrijs, Utrecht.

van Stokkom, H. T. C., A. J. M. Smits, and R. S. E. W. Leuven. 2005. Flood defense in the Netherlands. Water International 30(1):76-87. http://dx.doi.org/10.1080/02508060508691839

Vermaat, H. J., and G. Vermaat. 1997. De kronijken van Vermaat: van 1808 tot 1852. Van Wijk, Poortugaal.

Wouda, B. 2004. Rendabiliteit van buitengronden: de ingelanden van de Zuidpolder op IJsselmonde als investeerders en aandeelhouders. Holland: RegionaalHistorisch Tijdschrift 36:279-303.

Wouda, B. 2009. Een stijgende stand met zinkend land: waterbeheersingssystemen in polder Nieuw-Reijerwaard 1441-1880. Verloren, Hilversum.

Young, O. 2008. Institutions and environmental change: the scientific legacy of a decade of IDGEC research. Pages 3-45 in O. R. Young, L. A. King, and H. Schroeder, editors. Institutions and environmental change: principal findings, applications, and research frontiers. The MIT Press, Cambridge, Massachusetts, USA, and London, UK.

Zeischka, S. 2007. Minerva in de polder; Waterstaat en techniek in het Hoogheemraadschap van Rijland 1500-1865. Verloren, Hilversum. 


\section{WATER MANAGEMENT ARRANGEMENTS ON IJSSELMONDE IN THE LATE $18^{\mathrm{TH}}$ CENTURY}

\section{Introduction}

This attachment provides an overview of the water management arrangements on IJsselmonde at the end of the $18^{\text {th }}$ century. As explained in the main text, there were two types of water management entities on IJsselmonde: polders, which were responsible for the upkeep of the polder infrastructure, and local jurisdictions, which had a regulatory and judicial function. In addition, individual land users had maintenance obligations. In many cases these were limited to maintaining the small ditches on their land, but in the Zwijndrechtse waard individual land users were still responsible for the regular maintenance of the main dyke. The role of the province of Holland was limited: the Court of Holland acted as a court of appeal for the local jurisdictions, as well as a court of first instance for cases that could not be handled by the local jurisdictions.

The core of this attachment consists of a list of the local jurisdictions and a list of the polders on IJsselmonde. The list of polders also gives information on the common arrangements that existed between different polders and between different local jurisdictions.

\section{Local jurisdictions}

The list of local jurisdictions is based on a detailed contemporary description of Holland (van Ollefen 1993, Bakker 1798). For the western part of IJsselmonde this source gives both the number of houses and the population of the different jurisdictions. For the central and south-eastern part, however, it gives only the number of houses. These have been translated into population figures, using an average of 7.3 inhabitants per house, based on the data for the western part. This average may be a bit high. It is not clear whether always all houses have been counted or only the taxable houses and whether all inhabitants have been counted or only those above a certain age.

The surface area of the different local jurisdiction given by van Ollefen and Bakker is ultimately based on tax registers, hence on taxable land. This does not include public roads, open waters and possibly land that was exempted. Moreover, accuracy is unknown. Especially in the Zwijndrechtse waard, where most jurisdictions consisted of two or even more isolated parts (see the map in Jorissen 1955), it is not certain whether always the whole territory has been taken into account.

\section{Polders}

Listing the polders on IJsselmonde is less straightforward than listing the local jurisdictions. A polder in a technical sense is an area hydrologically isolated from its surroundings by means of dykes or low embankments. A polder has its own drainage system, usually discharging its excess water through a culvert or sluice by means of gravity or using a wind mill or pumping station. The problem is that the drainage systems of different polders may be connected with each other, permanently or temporarily, and sometimes it may be questionable whether they should still be considered as separate drainage systems and hence the polders as separate polders.

An administrative polder is a management unit with its own polder levy, officers and personnel, such as a treasurer, a secretary and a miller. Usually, administrative polders coincided with polders in a technical sense, but some polders in a technical sense were managed by more than one administrative polder and there were also administrative polders managing more than one polder in a technical sense. In the latter case, separate books were kept and the polder levies differed. It is sometimes hard to tell whether there 
was one administrative polder with separate bookkeeping or different administrative polders with for instance a common secretary.

The list of polders given below is primarily a list of polders in a technical sense. The list gives the surface area, the date or period of reclamation and the local jurisdiction or jurisdictions in which it was located. Moreover, it gives information on the administrative polder if this did not coincide with the polder in a technical sense; on supervision of the dykes if this was not the responsibility of the local jurisdiction; and on any common arrangements with other polders concerning drainage.

The dates of reclamation given are not always exact. Dated concessions of several polders exist, but not of the oldest polders and some of the newer polders did not need a concession. Moreover, reclamation works did not necessarily start immediately and could take some years. In a few cases polders could be dated because temporary tax exemptions were granted to promote reclamation (and future tax income) or because reclamation works are mentioned in a tax register (Tuijn s.d.: Buitenland van Rhoon). Often, areas were first surrounded with relatively low and cheap dykes, so-called summer dykes, that were allowed to be overtopped during winter floods. This resulted in new land that could be used as pasture. Only later were stronger "winter dykes" created to protect the land also against winter floods, allowing more profitable crops.

The most important source for the list of polders is Teixeira de Mattos (1920), which describes on 842 pages the polders on IJsselmonde, their surface area, the existing water management infrastructure, the management arrangements in 1920, and their historical background. However, this source often gives limited information about polders that had already been swallowed up by the harbor of Rotterdam. Teixeira de Mattos (1920) has been complemented with more recent literature, most notably Hoek (1969, 1973), and with information from the inventories of different polder archives. These inventories often contain informative introductions on the history of the polder concerned and sometimes provide summaries of the oldest charters in the polder archive (Ommeren 1964, Duinker 1965, Brilman 1967, Poelstra 1967, Streefland 1970, Nieuwenhuis 1980, Hordijk, 1983, Wouda and Vermeer 2008, Inventaris van het archief van het Waterschap De Oude ... date unknown, Inventaris van het archief van Waterschap De Koedood, date unknown). Some additional information was derived from van Ollefen (1993) and Bakker (1798) and van der Aa (1839-1851), especially on surface areas of polders not given in Teixeira de Mattos (1920).

It may be clear that the list of polders is not the definitive list: more detailed research on individual polders could result in more accurate information on reclamation dates, surface areas, drainage system and management arrangements.

\section{List of local jurisdictions}

Western part

1. Pernis

- 187 ha. (1732)

- 703 inhabitants

- Part of Putten

2. 's-Gravenambacht or Heyde en Boudewijn Hartsland

- 170 ha.

- 87 inhabitants

- Part of Putten 
3. Langebakkersoord met Oud- en Nieuw Smalland

- 266 ha.

- 14 inhabitants (2 houses)

- Part of Putten

4. Poortugaal

- 597 ha.

- 548 inhabitants

- Part of Putten

5. Hoogvliet

- 234 ha.

- 446 inhabitants

- Part of Putten

6. Lokhorsterland or Oud- en Nieuw Engeland

- 110 ha.

- 26 inhabitants

- Part of Putten

7. Albrandswaard met de Kijvelanden

- 185 ha.

- Ca. 160 inhabitants

- A so-called, "high jurisdiction" with its own bailiff, appointed by the Lord of Albrandswaard

Former Riederwaard (central part)

8. Rhoon

- 736 ha.

- 650 inhabitants

- A so-called, "high jurisdiction" with its own bailiff, appointed by the Lord of Rhoon and Pendrecht

9. Pendrecht

- 90 ha.

- 18 inhabitants

- A so-called, "high jurisdiction" with its own bailiff, appointed by the Lord of Rhoon and Pendrecht

10. Ridderkerk

- 1490 ha.

- 2920 inhabitants

11. Oost-IJsselmonde

- 500 ha.

- About 1170 inhabitants (including West-IJsselmonde)

12. West-IJsselmonde

- 514 ha.

- Inhabitants: see Oost-IJsselmonde

13. Charlois

- 1422 ha.

- Ca. 1500 inhabitants

- Part of Putten

14. (Oud-)Katendrecht

- Ca. 85 ha.

- Ca. 350 inhabitants (1749)

- Part of Putten 
15. Oost-Barendrecht

- 540 ha.

- Ca. 525 inhabitants

16. West-Barendracht

- 355 ha.

- Ca. 500 inhabitants

17. Carnisse

- 370 ha.

- Ca. 500 inhabitants

18. Alblasserdam

- Mostly located across the river Merwede: only polders 44-46 became attached to IJsselmonde when the river changed its course

Zwijndrechtse waard (south-eastern part)

19. Schobbelandsambacht or Zwijndrecht

- 147 ha.

- Ca. 880 inhabitants

20. Molenambacht or Meerdervoort

- 73 ha.

- Ca. 500 inhabitants

21. Groote Lindt

- 266 ha.

- Ca. 400 inhabitants

22. Kleine Lindt

- 202 ha.

- Ca. 220 inhabitants

23. Heer Oudelands Ambacht

- 202 ha.

- Ca. 150 inhabitants

24. Kijfhoek

- 295 ha.

- Ca. 220 inhabitants

25. Heerjansdam

- 253 ha.

- Ca. 700 inhabitants

26. Rijsoord

- Ca. 190 ha.

- Ca. 100 inhabitants (together with Strevelhoek)

27. Strevelshoek

- Ca. 190 ha.

- Ca. 100 inhabitants (together with Rijsoord)

28. Sandelingenambacht

- 295 ha.

- Ca. 230 inhabitants

29. Hendrik-Ido-Ambacht

- 295 ha.

- Ca. 1280 inhabitants 
30. Schildmanskinderenambacht

- About 155 ha.?

- Population unknown but small

31. Heinenoord

- Mostly located across the river Oude Maas: only polder Lage Nesse (nr. 66) attached to Zwijndrechtse waard

\section{List of polders}

Western part

1. Land van Poortugaal

- 847 ha.

- Ca. 1180 (Welhoek), before 1295 (Oud-Pernis), between 1180 and 1295 (1e uitleg) and ca. 1295 (Ommeloop)

- Poortugaal, Hoogvliet and Pernis

- Three separate administrative polders: Welhoek en het Ambacht van Poortugaal (532 ha.). Het Ambacht van Hoogvliet (274 ha.), and Oud-Pernis (41 ha.)

- Dyke management by water board Gemeeneland van Poortugaal, which was also responsible for the polder mills and some drainage canals

2. Nieuw-Pernis

- 40 ha.

- Around 1300 (after Ommeloop and before 3)

- Pernis

- Dyke management by water board Gemeeneland van Poortugaal

- Common polder mill with 3,4 and 20

3. Lombardijen

- 57 ha.

- Ca. 1300,1357

- Pernis

- Dyke management by water board Gemeeneland van Poortugaal

- Common polder mill with 2, 4 and 20

4. Deijffel

- 82 ha.

- 1318

- Dyke management by water board Gemeeneland van Poortugaal

- Common polder mill with 2, 3 and 20

5. Roozand

- 90 ha.

- 1357

- Poortugaal

- Dyke management by water board Gemeeneland van Poortugaal

- Based on an agreement of 1645, this polder drained for free onto 1.

6. Oud-Engeland

- 15 ha.

- 1415

- Lokhorsterland

- Dyke management by water board Gemeeneland van Poortugaal 
7. Oud-Smalland

- 60 ha.

- 1487 (together with 8 and 9)

- Langebakkersoord

8. Langebakkersoord

- 170 ha.

- 1487 (together with 7 and 9)

- Langebakkersoord

9. Nieuw-Engeland

- 120 ha.

- 1487 (together with 8 and 9)

- Lokhorsterland

10. Deijffelsbroek

- 75 ha.

- Before 1611

- Pernis

11. Madroel

- 17 ha.

- $17^{\text {th }}$ century?

- Pernis

12. Nieuw-Smalland

- 22 ha.

- Before 1686

- Pernis

13. Polder Jaagin en Hoge en Lage Gorzen

- 64 ha. (Jaagin 17 ha., Hoge en Lage Gorzen 47 ha.)

- Before 1812 (Jaagin possibly oldest part)

- Pernis

- In 19th century two separate administrative polders, but at the time within one dyke

14. Elderspolder

- 31 ha.

- Late $18^{\text {th }}$ century or later, but before 1809

- Hoogvliet

15. Albrandswaard

- 227 ha.

- 1411

- Albrandswaard en de Kijvelanden, Poortugaal (Volgerlanden) and Rhoon (Binnenland Buitendijks, 11 ha.)

16. Binnen Kijvelandse polder

- 30 ha.

- Between 1561 and 1663

- Albrandswaard en de Kijvelanden

17. Buiten Kijvelandse polder

- 33 ha. (including Slobber gorzen)

- Between 1561 and 1663

- Albrandswaard en de Kijvelanden 
18. Slobber gorzen

- 33 ha. (including Slobber gorzen)

- Possibly 17th century

- Albrandswaard en de Kijvelanden

19. Geneverpolder en Kooipolder

- 52 ha.

- Before 1777?

- Albrandswaard en de Kijvelanden

Former Riederwaard (central part)

20. Boudewijn Hartsland

- 110 ha.

- 1455

- 's-Gravenambacht

- Common polder mill with 2, 3 and 4

21. De Kiesheid

- 163 ha.

- Shortly after 1580

- 's-Gravenambacht, 14 ha. in Rhoon (Rhoonse Kiesheid and Buitenland buitendijks)

- Since 1654 drainge onto the Koedood

22. Zwaardijk

- 65 ha.

- 1382,1423

- Poortugaal

- Common polder mill with Binnenland van Rhoon (23-29)

23. Oud-Rhoon

- 33 ha. (together with 24-29 404 ha.)

- $1368 / 1369$

- Rhoon

- Administrative polder Binnenland van Rhoon, which has a common dyke reeve and dyke council with Buitenland van Rhoon (30). It is unclear whether in 1795 Oud-Rhoon could still be considered a separate polder in a technical sense.

- Drainage onto the Koedood

24. De Huiters en Kortambacht

- 1411 and 1423

- See further under Oud-Rhoon, but Kort ambacht in Poortugaal

25. Klein Kijfhoek

- See under Oud-Rhoon

26. Kijfhoek

- 58 ha. (possibly including Klein Kijfhoek)

- Before 1556

- See further under Oud-Rhoon

27. Ghijseland

- 55 ha.

- Before 1556

- See further under Oud-Rhoon 
28. Jan Cornelis polder

- 27 ha.

- Before 1556

- See further under Oud-Rhoon

29. Polder Jaagin

- See under Oud-Rhoon

30. Het Buitenland van Rhoon

- 401 ha.

- Some already reclaimed in 1556 , but reclamation works ongoing in 1556

- Rhoon

- Common dyke reeve and dyke council with administrative polder Binnenland van Rhoon

- Polder mill drains 36 as well. Drainage onto the Koedood

31. Molenpolder

- 121 ha.

- 1642

- Rhoon

- Common polder mill with 32

32. Zegenpolder

- 150 ha.

- 1675

- Rhoon

- Common polder mill with 31

33. Portlandse Polder

- 160 ha.

- 1769

- Rhoon (and Pendrecht?)

34. Oud-Pendrecht

- 38 ha.

- Between 1461 and 1539

- Pendrecht

- Drainage through 53 onto Koedood

35. Nieuw Pendrecht

- 136 ha.

- Ca. 1580

- Pendrecht

- Drainage onto Koedood

36. De Stee van Pendrecht

- 50 ha.

- Ca. 1580

- Pendrecht

- Drainage by polder mill of 30

37. Binnenland van Barendrecht

- 758 ha.

- 1484. Previously partial reclamation works within jurisdictional boundaries.

- Oost-Barendrecht, West-Barendrecht, Carnisse and Ridderkerk (Veren-Ambacht, 46 ha.)

- Drainage onto Koedood. Supervision of the polder infrastructure by representatives from the first three jurisdiction, presided by the dyke reeve of the jurisdiction in which the infrastructure was located. 
38. Ziedewij

- 126 ha.

- Between 1484 and 1496

- Oost-Barendrecht

39. Buitenland van Barendrecht

- 454 ha.

- Concession 1551, ready 1555

- Oost-Barendrecht, West-Barendrecht and Carnisse

- Since 1661 drainage through 40. Supervision as 37.

40. Zuidpolder

- 464 ha.

- 1650 , except for 13 ha. that were reclaimed before (Onderende van Nieu Liesvelt)

- Oost-Barendrecht, West-Barendrecht and Carnisse

- Supervision as 37

41. Vredepolder

- 37 ha.

- $1712 / 1713$

- West-Barendrecht

- Owned by the Zuidpolder

42. Oud-Reijerwaard

- 546 ha.

- 1404

- Ridderkerk

43. Nieuw Reijerwaard

- 1081 ha.

- 1442

- $\quad$ Ridderkerk, Barendrecht (Cornelisland, 36 ha.)

- Supervision of its dykes together with 47

44. Woude

- 52 ha.

- Ca. 1500 ?

- Ridderkerk

45. Voor-Donkersloot

- 65 ha.

- Before 1491

- Alblasserdam

- Originally not a part of IJsselmonde, but became attached to IJsselmonde after the River Merwede changed its course in the late 14th century

46. Ronde Zand

- 77 ha.

- Ca. 1500

- Ridderkerk and possibly Alblasserdam

- See under 45

47. Oost-IJsselmonde

- 535 ha.

- $1436 / 37$ (part called Oude land (old land) possibly older)

- Oost-IJsselmonde

- Supervision of its dykes together with 43 
48. Dirk Smeetsland en Mr. Aernt vander Woudeland

- 366 ha.

- Originally two polders: Dirk Smeetsland, recclaimed 1432, 1468, Mr. Aernt vander Woudeland 1444,1468

- West-IJsselmonde and Charlois

- Complicated arrangements with 49 and 50 on drainage

49. De laagjes of 68 morgen

- 66 ha.

- Before 1505

- West-IJsselmonde

- Complicated arrangements with 48 and 50 on drainage

50. Klein-Nieuwland of de 51 morgen

- 48 ha.

- Before 1505

- West-IJsselmonde

- Complicated arrangements with 48 and 49 on drainage

51. Varkensoord and Karnemelksland

- 257 ha.

- 1566: agreement on summer dyke, 1694: winter dyke

- West-IJsselmonde (Varkensoord) and Charlois (Karnemelksland)

- Two separate administrative polders that held joint meetings, plus a water board in charge of, among others, the dyke.

52. Zomerland

- 20 ha.

- Before 1733

- West-IJsselmonde

53. Polder (Oud-)Katendrecht

- 85 ha.

- In or before $1394,1410,1446$

- (Oud-)Katendrecht

54. Polder Charlois

- Ca. 1000 ha.

- 1462

- Charlois

55. Hille

- 233 ha.

- 1529

- Charlois

56. Robbenoord en de Plompert

- 472 ha.

- Robbenoord: 1493, 1535, 1581 (winter dykes), Plompert: 1581

- Charlois

- Drainage onto Koedood

Zwijndrechtse waard (south-eastern part)

57. Polder Hendrik-Ido-Ambacht

- 640 ha.

- 1332-1336 
- Hendrik-Ido-Ambacht plus parts of nearly all other jurisdictions in the Zwijndrectse waard ("Volgerlanden": plots of second-class agricultural land in the north-eastern corner of the Zwijndrechtse waard)

- Supervision of the dykes by water board Zwijndrechtse waard

- Drainage on the Waal with 58, 59 and 60 ("Waalpolders")

58. Polder Sandelingen-Ambacht

- Ca. 300 ha.

- $1332-1336$

- Sandelingen-Ambacht

- Supervision of the dykes by water board Zwijndrechtse waard

- Drainage on the Waal with 57, 59 and 60 ("Waalpolders")

59. Polder Heerjandsdam

- Ca. 200 ha.

- 1332-1336

- Heerjansdam

- Supervision of the dykes by water board Zwijndrechtse waard

- Drainage on the Waal with 57, 58 and 60 ("Waalpolders")

59. Polder Rijsoord en Strevelshoek

- Ca. 230 ha.

- 1332-1336

- Rijsoord, Strevelshoek

- Supervision of the dykes by water board Zwijndrechtse waard

- Drainage on the Waal with 57, 58 and 59 ("Waalpolders")

61. Polder Zwijndrecht

- Ca. 320 ha.

- $1332-1336$

- Zwijndrecht, Meerdervoort, Kortambacht

- Supervision of the dykes by water board Zwijndrechtse waard

- Drainage onto the Devel, joint management with other Devel polders of wind mill draining the Devel

62. Polder Heer Oudelands-Ambacht

- Ca. 225 ha.

- $1332-1336$

- Heer Oudelands-Ambacht

- Supervision of the dykes by water board Zwijndrechtse waard

- Drainage onto the Devel, joint management with other Devel polders of wind mill draining the Devel

63. Polder Kijfhoek

- Ca. 230 ha.

- $1332-1336$

- Kijfhoek

- Supervision of the dykes by water board Zwijndrechtse waard

- Drainage onto the Devel, joint management with other Devel polders of wind mill draining the Devel

64. Polder Groote en Kleine Lindt

- Ca. 320 ha.

- $1332-1336$

- Grote Lindt, Kleine Lindt 
- Supervision of the dykes by water board Zwijndrechtse waard

- Drainage onto the Devel, joint management with other Devel polders of wind mill draining the Devel

65. Westeinde van de Hooge Nesse

- 71 ha.

- Before 1665 , possibly 1435

- Kleine Lindt

66. Oosteinde van de Hooge Nesse

- 56 ha.

- Before 1665 , possibly 1435

- Grote Lindt

67. Lage Nesse or Polder Buitenland

- 60 ha.

- Possibly 1435

- Heinenoord

68. Groote Noord

- 16 ha.

- After 1783 but before 1812

- Hendrik-Ido-Ambacht

69. Noordpolder

- 24 ha.

- Before 1812

- Probably Heer Oudelands-Ambacht and Schildmanskinderenambacht

\section{LITERATURE CITED}

Brilman, D. 1967. De Archieven van de voormalige polders onder Katendrecht, Charlois, Pernis en Hoogvliet. Rotterdam.

Duinker, P. F. 1965. Inventaris van het archief van de Develpolder. Provinciale inspectie van de gemeente- en waterschapsarchieven in Zuid-Holland, Den Haag. [online] URL:

$\mathrm{http}: / / \mathrm{www} \cdot \operatorname{archieven} . \mathrm{nl} / \mathrm{nl} /$ zoeken? mivast=0\&mizig=210\&miadt=46\&micode=729\&miview=inv2 .

Hoek, C. 1969. De oudste heren van Rhoon; Een bijdrage tot de geschiedenis van enkele geslachten, gegoed in de verdronken Riederwaard. De Nederlandsche Leeuw; Maandblad van het Koninklijk Nederlandsch Genootschap voor Geslacht- en Wapenkunde 86:232-273.

Hoek, C. 1973. Pernis zonder olie. Holland; Regionaal-historisch tijdschrift 5:181-195.

Hordijk, L. W. 1983. Inventaris van de archieven van de polder Binnenland en Ziedewij. Waterschap IJsselmonde, Brielle. [online]

Inventaris van het archief van Waterschap De Koedood. [date unknown]. [online] URL:

$\mathrm{http}: / / \mathrm{www}$. archieven.nl/nl/zoeken?mivast=0\&mizig=210\&miadt $=184 \&$ micode $=1355 \&$ miview $=$ inv2

Inventaris van het archief van het Waterschap De Oude en Nieuwe Maasdijken voor het Land van Rhoon. [date unknown]. [online] URL:

$\mathrm{http}: / / \mathrm{www} \cdot \operatorname{archieven} . \mathrm{nl} / \mathrm{nl} / \mathrm{zoeken}$ ?mivast=0\&mizig=210\&miadt=184\&micode=1346\&miview=inv2

Jorissen, F. 1955. Het Hoogheemraadschap van de Zwijndrechtse Waard; Februari 1331 - Februari 1955. Hendrik-Ido-Ambacht. 
Nieuwenhuis, J. G. B. 1980. Inventaris van de archieven van de polders onder de voormalige gemeente IJsselmonde. Rotterdam. [online] URL:

$\mathrm{http} / /$ www.archieven.nl/nl/zoeken?mivast=0\&mizig=210\&miadt=184\&micode=14\&miview=inv2

Bakker, R. 1798. De Nederlandsche stad- en dorp-beschrijver; VI. deel. het Land van Voorne en Putten, Overflaque, Portugal. H.A. Banse, Amsterdam.

Ommeren, H. R. v. 1964. Het archief en de handschriften van de grondheerlijkheid "Charlois en annexe polders", 1460-1887. Rotterdam. [online] URL:

$\mathrm{http} / /$ www.archieven.nl/nl/zoeken?mivast=0\&mizig=210\&miadt=184\&micode=12\&miview=inv2

Poelstra, T. J. 1967. Inventaris van het archief van de polder de Hille onder de gemeente Charlois. Rotterdam. [online] URL:

$\mathrm{http}: / / \mathrm{www}$. archieven.nl/nl/zoeken?mivast=0\&mizig=210\&miadt=184\&micode=13.03\&miview=inv2

Streefland, J. H. 1970. Inventaris van het archief van het hoogheemraadschap van de Zwijndrechtse Waard. Den Haag. [online]

Teixeira de Mattos, L. F. 1920. De waterkeeringen, waterschappen en polders van Zuid-Holland. Dl. 6. De eilanden (vervolg). Afd. 2. Het eiland IJsselmonde. Nijhoff, 's-Gravenhage.

Tuijn, A. v. d., editor. s.d. Archief van de Staten van Rhoon voor 1572. Kohier van de 10e penning van 1556, inventaris nummer 1088, Rhoon; bewerking. [online] URL:

http://www.hogenda.nl/Docs/Attachment.aspx?ID=\{ ebdc64b9-7db1-4d47-b3b6-03fbb5e3b232 $\}$

van der Aa, A. J. 1839-1851. Aardrijkskundig woordenboek der Nederlanden. J. Noorduyn en Zoon, Gorinchem.

van Ollefen, L. 1793. De Nederlandsche stad- en dorp-beschrijver; I. deel. 't Eiland van Dordrecht, de Hoeksche waard, de Zwijndrechtse waard, en 't Land van IJsselmonde. H.A. Banse, Amsterdam.

Wouda, B. and T. H. Vermeer. 2008. Inventaris van het archief van de Zuidpolder. Rotterdam. [online] URL:

$\mathrm{http} / / / \mathrm{www} \cdot \operatorname{archieven} . \mathrm{nl} / \mathrm{nl} /$ zoeken$?$ mivast=0\&mizig=210\&miadt=184\&micode=1359\&miview=inv2 


\section{WATER MANAGEMENT ARRANGEMENTS ON IJSSELMONDE IN 1920}

\section{Introduction}

This attachment presents the water management system on IJsselmonde in 1920, focusing on the formal arrangements for flood protection and drainage. In summary, the dykes and the main drainage infrastructure were managed by 57 different water boards and the municipality of Rotterdam. The Province of South-Holland had an important supervisory task. National government had final supervision, was responsible for the legislative framework, and appointed the members of water boards responsible for river dykes. The landholders in the area of the different water boards financed the water boards through a water board charge, were responsible for minor maintenance works, and elected the members of their boards or, as the case may be, voted on recommendations for new members. Moreover, they were consulted on several issues and could appeal against many decisions to the province or national government. Together with other citizens, they had voting rights for the provincial council and for national parliament.

In this attachment, more details will be given on the water boards, the municipality of Rotterdam, the Province of South-Holland and national government. Moreover, a list will be given of all the water boards with some specifics. The main sources of this attachment are Teixeira de Mattos (1920), Monchy and Loon (1954) and Kooiman (1928-1932).

\section{Water boards}

\section{Numbers and tasks}

Within the ring formed by the main dykes of IJsselmonde, there were 40 water boards. Their tasks were the following (numbers refer to the list at the end of this attachment):

- $\quad$ Two water boards managed river dykes $(1,2)$

- Two water boards managed river dykes as well as common drainage works of several polders $(27,33)$

- $\quad$ Four water boards managed the river dykes and drainage works of individual polders (21, $24,25,26$,)

- Twenty-nine water boards managed only the drainage works of individual polders, including one that did not have the statute of a water board (12)

- $\quad$ Three water boards managed a pumping station and other drainage works serving several polders $(3,14,22)$

Many water boards were also responsible for roads, but roads will not be discussed further in this attachment.

Outside of the main dyke ring there were 17 small water boards protected by low dykes only. They were all responsible both for these dykes and for drainage of their area. Four were owned and managed by another water board (44-47), and seven were owned by another single owner $(41,48,50,52,55-57)$.

In addition to these 17 water boards, there were more than 30 small and very small polders outside of the main dyke ring without a water board statute. These were privately managed. 


\section{Composition}

The water boards consisted of two organs: the governing board, consisting of a chair person and usually two to five ordinary members, and a body representing the landholders ("ingelanden": owners, usufructuaries and hereditary tenants of land in the water board area). These organs were supported by a secretary, a treasurer and other staff, such as a mechanic for the water board's pumping station. The functions of secretary and treasurer were often combined and could be combined with that of chair person.

The governing board was in charge of the daily management of the water board and had some regulatory powers. The board could adopt byelaws concerning the water board's tasks, provided there was no provincial byelaw or national regulation that already regulated the issue. Moreover, the board controlled implementation, decided on maintenance obligations by third parties and could adopt target water levels for the surface waters. The body representing the landholders was competent in financial matters or matters with financial implications The landholders had to approve the budget and determine the tariff for the water board charges. Moreover, they decided on all new and exceptional works, on taking loans, the sale and lease of the water board's property and on permanent contracts to be concluded by the board.

Governing board members held office for periods of six years (five years in the case of 1 and 2) and had to hold at least one hectare of land in the water board area. In case of water boards that did not manage the main river dykes, the board members were normally elected by all persons and legal entities holding at least one hectare of land in the water board area. The number of votes they could cast depended on the size of their landholding, ranging from one for landholdings between one and two hectares, to 20 for landholdings between 191 and 210 hectares and one additional vote for every additional 25 hectare, up to a maximum of $25 \%$ of all the votes in the water board. Landholders holding less than one hectare could register together with others and then got one vote if together they held one hectare or more. Since 1913, female landholders could vote in person and did not need a male guardian anymore, provided they were in charge of managing their own property, which married women usually were not.

Governing board members of water boards responsible for the main river dykes were appointed by the "Crown", in practice the Minister of Public Works. Normally, the landholders could recommend three persons for each post, and those receiving most votes would be recommended to the Crown, who could then select one.

In the smaller water boards, the body representing the landholders consisted of all individual landholders in person. In one larger water board, the landholders elected representatives (33) and in four the landholders were represented by the elected board members of the different polders in the water board's territory $(1-3,14$,$) . In these cases the governing board members were not$ elected or recommended by all landholders, but by their representatives. The land holders or their representatives did not decide on the water board's byelaws, but draft byelaws had to be put on public display during 30 days, and during this period all interested parties could send in their comments. Moreover, there were possibilities for appeal (see below).

The composition of the water boards was more simple in case there were less than seven landholders with voting rights. In that case, the landholders would form the governing board and together they had to appoint or recommend to the Crown one representative. In case there was only one owner, the owner or someone appointed by him or her would represent the water board. 


\section{Funding}

The water boards were funded by means of a charge per hectare, levied from the landholders. In some water boards consisting of distinct parts, different tariffs were used for the different parts (4, $5,13,16,17,18,14,27,33,36,42,43)$. This was the case in many water boards that were the result of a merger or managed works benefitting different polders, but not in the same degree. Other reasons for differentiation included old agreements and exemptions and different service levels (e.g. artificial drainage in some parts and drainage by means of gravity in another: 43).

Two polders owned so much real estate generating income that they did not have to levy any charge and even paid money to the other landholders in the polder, in much the same way as companies pay dividend to their shareholders $(23,24$; cf. Wouda 2004). By law, if a water board was merged with another, split or abolished, the net assets had to benefit the landholders of that water board.

Since in large parts of the island maintenance of the river dykes and drainage were the responsibility of different water boards, many landholders had to pay two different charges: one to the water board in charge of dyke maintenance and one to the water board managing drainage. In the centre of the island, there were still two polders where the landholders did not contribute anything to the maintenance of the river dykes $(20,23)$.

\section{Municipality of Rotterdam}

In the late 19th century, Rotterdam started to expand rapidly and by 1920 five polders had been turned partly $(31,32)$ or completely (polders nr. 52, 54 and 55 in Attachment 1) into harbor area or residential areas. In these areas, Rotterdam took over responsibility for dyke management and drainage, and the old polders were abolished or reduced in size. The two pumping stations of Rotterdam also drained the remainder of two polders (31 and 32).

\section{Province}

Provincial government consisted of a provincial council and an executive committee out of this council, both chaired by the "Commissioner of the King", appointed by the Crown. The provincial council was directly elected, but women could vote from 1923 onwards only.

According to art. 190 of the constitution, the provincial council supervised all public works and all water boards in their province. Moreover, they could change the organization and statutes of the water boards, abolish existing and establish new ones, and make statutes for these. Pursuant to this provision, the provincial council of South-Holland had adopted statutes for each water board. Moreover, it had made a general polder byelaw for water boards managing individual polders, usually called "polder" themselves. These statutes and this byelaw contained rules on for instance the territory and the tasks of the boards, on voting rights and elections, on the personnel of the boards and remuneration, on the frequency of the board meetings, on decision-making procedures, on the charges and the budgetary process and on maintenance obligations by third parties.

A number of decisions of the water boards required approval by the executive committee of the province. These included the adoption or modification of a byelaw, taking loans, the sale of real estate, starting legal actions and the conclusion of permanent contracts. In most cases, interested 
parties could appeal against the decision of the executive committee to the Crown. If the executive council did not have to approve a water board decision, it could still nullify the decision at its own initiative, but only if it conflicted with national or provincial regulations, the statutes of the water board, the national interest, or the interest of the province or another water board. In this case appeal to the Crown was always possible.

The executive committee also decided in case of conflicts between the governing board and the body representing the landholders and conflicts between different water boards. In the latter case, water boards could appeal against the decision to the Crown.

Moreover, plans for new river dykes and coastal defences required approval by the executive committee. Following the storm surge of 22-23 December 1894, the provincial council adopted a provincial byelaw determining which dykes would form the main dyke ring of IJsselmonde and how high these dykes should be. At the same time two water boards (1 and 2) were established in the western part of the island to take over the management of the dykes from the many small polders that until then had been in charge.

While the provincial council could abolish existing and establish new water boards, they needed for this the approval of the Crown. Before they could make a proposal to that extent, they first had to inform all interested parties and give them the opportunity to react.

The province also managed some water management works itself, but not on IJsselmonde (van der Gouw 1975).

\section{National government}

National government consisted of parliament and the Crown. Parliament consisted of two chambers: the Second Chamber, which was directly elected (from 1922 onwards also by women) and the First Chamber, which was elected by the provincial council members. The Crown consisted of the Queen, with limited political responsibility, and the cabinet ministers. The cabinet ministers were accountable to parliament and had to abdicate if they lost the trust of parliament.

According to the constitution, national government was responsible for the national legislative framework and had ultimate supervision ("oppertoezicht") over all public works. In addition, it managed water management works itself, but not on IJsselmonde. As discussed above, the Crown appointed members of water boards responsible for river dykes (and coastal defences). Moreover, it was possible to appeal to the Crown against several decisions of the executive committee of the province. The Crown could also nullify any decision of the provincial council or executive committee at its own initiative if this decision conflicted with the law or the general interest.

Moreover, new land reclamation work needed a concession by the Crown, which the Crown could give only after advice from the provincial executive committee. The executive committee had to put applications for a concession on public display during 30 days and process the comments received before giving advice.

Much of the national legislation was meant to provide the provinces and the water boards the means to make and enforce rules and take action during emergencies. For instance, the Competencies act ("Bevoegdhedenwet") gave the water boards the power to take all necessary action in case of a flood threat or an actual flood, to remove illegal works and recover the costs 
from the culprits, and to seize property of people who did not pay the water board charges, without prior consent by a court of law. Judicial review of decisions was possible only afterwards to ensure that the water board could take timely action and continue to function in case of conflicts.

\section{List of water boards}

NB: Numbers of former polders refer to the list of polders in Attachment nr. 1.

\section{A: Within the main dyke ring}

1. Water board the old and new Meuse dykes in front of Rhoon

- River dykes only

- Polders within its territory: 5 (Boudewijn Hartsland), 13, 15-19, 32 (Oud-Pendrecht)

2. Water board the West dykes of IJsselmonde

- River dykes only

- Polders within its territory: 4, 5 (excluding Boudewijn Hartsland), 6-12

3. Waterschap van de gemeenschappelijke uitwatering met bepaling van de polders "het land van Poortugaal" en "de polders Pernis c.a."

- Managing common pumping station of 4 and 5 that also drains 6

4. Het Land van Poortugaal

- Drainage only

- Former polder 1

5. De polder Pernis c.a.

- Drainage only

- Former polders 2, 3, 4, 6 and 20

6. Polder Roozand c.a.

- Drainage only

- Discharge its drainage water for free onto 3, based on an agreement of 1645

- Former polder 5

7. Polder Deijffelsbroek

- Drainage only

- Former polder 10

8. Polder Oud-Smalland

- Drainage only

- Former polder 7

9. Polder Langebakkersoord

- Drainage only

- Former polder 8

10. Polder Nieuw-Engeland

- Drainage only

- Former polder 9

11. Elderspolder

- Drainage only

- One owner

- Former polder 14

12. Polder Meeuwenoord

- Drainage only 
- No statute, so officially not a water board, but contributing for dyke maintenance to 2

- 12 ha., created before 1812 (figure 1, called "Meeuw gors")

13. Polder Albrandswaard

- Drainage only

- Former polder 15

14. Waterschap de Koedood

- Managing common drainage works of the polders 15, 16, 17, 19 and 20

15. Polder de Kiesheid

- Drainage only

- Former polder 21

16. Polder Binnenland van Rhoon

- Drainage only

- One statute with 17. Two separate boards that were combined when decisions had to be taken on a number of common issues, such as a sluice serving both polders

- Former polders 22-29

17. Het Buitenland van Rhoon

- Drainage only

- One statute with 16: see supra.

- Former polders 30 and 36

18. Polder Zegen-, Molen en Portlandpolders

- Drainage only

- Former polders 31, 32 and 33

19. Polder Nieuw-Pendrecht

- Drainage only

- Former polders 30 and 35

20. Polder Binnenland van Barendrecht

- Drainage only

- Landholders did not contribute to dyke maintenance

- Former polder 37

21. Polder Ziedewij

- River dykes and drainage

- Former polder 38

22. Waterschap gemeenschappelijke Stoombemaling van de polders Buitenland en Zuidpolder

- Managing common pumping station of 23 and 24

23. Polder Buitenland (Barendrecht)

- Drainage only

- Landholders did not contribute to dyke maintenance

- Since the polder owned a lot of land, the other landholders did not have to pay a polder levy and sometimes even received money from the polder

- Former polder 39

24. Zuidpolder (Barendrecht)

- River dykes and drainage

- Since the polder owned a lot of land (polders 44-47), the landholders did not have to pay a polder charge and instead received substantial income from the polder

- Former polder 40

25. Polder Reijerwaard

- River dykes and drainage

- Common dyke inspection with 26

- Former polders 42 and 43 
26. Polder Oost-IJsselmonde

- River dykes and drainage

- Common dyke inspection with 25

- Former polder 47

27. Waterschap van West-IJsselmonde

- River dykes and some common drainage works

- Polders within its territory: 28-30

28. Polder Dirk Smeetsland en Meester Arend van der Woudenland

- Drainage only

- Former polder 48

29. Polder Acht-en-zestig morgen

- Drainage only

- Former polder 49

30. Polder het Klein-Nieuwland of de 51 morgen

- Drainage only

- Former polder 50

31. Polder Varkensoord en Karnemelksland

- Drainage only, using pumping station of Rotterdam

- Former polder 51 (partly)

32. Polder Charlois

- Drainage only, using pumping station of Rotterdam

- Former polders 53 (partly) and 34

33. Hoogheemraadschap Zwijndrechtse waard

- River dykes and some common drainage works

- Polders within its territory: 34-40

34. Polder Hendrik-Ido-Ambacht

- Drainage only

- Former polder 57

35. Polder Sandelingenambacht

- Drainage only

- Former polder 58

36. Polder Heerjandsdam, Rijsoord en Strevelshoek

- Drainage only

- Former polders 59 and 60

37. Polder Zwijndrecht

- Drainage only

- Former polder 61

38. Polder Heer Oudelands-Ambacht

- Drainage only

- Former polder 62

39. Polder Kijfhoek

- Drainage only

- Former polder 63

40. Polder Groote en Kleine Lindt

- Drainage only

- Former polder 64 
B: Outside of the main dyke ring (excluding areas that in 1920 were still separate islands and were attached to IJsselmonde only after 1953)

NB: All water boards outside of the main dyke ring were responsible for both their dykes and for drainage.

41. Polder het Zomerland

- One owner

- Former polder 52

42. Polder Vóór-Donkersloot en Woude

- $\quad$ Former polders 44 and 45

43. Polder het Zand

- Drainage onto 25, based on contract

- Former polder 46

44. Polder Spuiveld

- Managed by the board of 24, owner of the polder

- 12 ha., created partly before 1834 , enlarged between 1850 and 1866

45. Vredepolder

- Managed by the board of 24, owner of the polder

- Former polder 41

46. Jan-Gerritzepolder

- Managed by the board of 24, owner of the polder

- 62 ha., created before 1848 (Municipal archive Rotterdam, Zuidpolder (Barendrecht), inv.nr. 497)

47. Carnissepolder

- Managed by the board of 24, owner of the polder

- 5 ha., created 1863

48. Johannapolder

- Since 1900, when water board 1 built a new dyke through the polder, partly within the main dyke ring

- Owned completely by the Municipality of Rotterdam

- 20 ha., created 1804 (Municipal archive Rotterdam, Ambacht en Gemeente Albrandswaard, inv.nr. 462)

49. Buiten-Kijveland en de Slobbegorzen

- Former polders 17 and 18

50. Jenever- en Kooipolder

- Owned completely by the Municipality of Rotterdam

- Former polder 19

51. Polder Oud- en Midden-Kijveland of het Binnen-Kijveland

- Former polder 16

52. Zuidpolder of het Gijpland

- Undivided property of two families

- 74 ha., created probably second half of the 18 th century

53. Polder Jaagin

- One dyke with 54

- Part of former polder 13

54. Polder de Hoogen en Lagen Gorzen

- One dyke with 53

- Part of former polder 13 
55. Polder Nieuw-Smalland

- One owner

- Former polder 12

56. Buitengronden genaamd Madroel

- One owner

- Former polder 11

- Area raised. Technically not a polder anymore, statute officially still valid but not applied

57. De Gorzenpolder en de Hey

- One owner

- 22 ha., created in or before 1839 (Municipal archive Rotterdam, Gorzenpolder en de Hey, inv.nr. 1)

\section{LITERATURE CITED}

Kooiman, D. 1928-1932. Waterstaatswetgeving. Alphen aan de Rijn, N. Samson.

Monchy, S. J. R. and P. v. Loon. 1954. Algemeen reglement voor de polders in de provincie ZuidHolland; Met uitvoeringsvoorschriften en van aantekeningen voorzien. Samsom, Alphen aan den Rijn.

Teixeira de Mattos, L. F. 1920. De waterkeeringen, waterschappen en polders van Zuid-Holland. Dl. 6. De eilanden (vervolg). Afd. 2. Het eiland IJsselmonde. 's-Gravenhage, Martinus Nijhoff.

van der Gouw, J. L. (ed.) 1975. Honderd jaar Provinciale Waterstaat in Zuid-Holland. 'sGravenhage, Provinciale Waterstaat in Zuid-Holland.

Wouda, B. 2004. Rendabiliteit van buitengronden: de ingelanden van de Zuidpolder op IJsselmonde als investeerders en aandeelhouders. Holland; Regionaal-historisch tijdschrift 36:279-303. 